\title{
Two New Phenylpropanoid Glycosides from the Aerial Parts of Paederia scandens
}

\author{
Young-Won Chin, ${ }^{\dagger,+}$ Kee Dong Yoon ${ }^{\dagger}$ Mi-Jeong Ahn, ${ }^{\S}$ and Jinwoong Kim ${ }^{\dagger, *}$ \\ ${ }^{\dagger}$ College of Pharmacy and Research Institute of Pharmaceutical Science, Seoul National University, \\ Seoul 151-742, Korea*E-mail:jwkim@snu.ac.kr \\ ${ }^{\ddagger}$ Immune Modulator Research Center, Korean Research Institute of Bioscience and Biotechnology, \\ Ochangeup, ChungBuk 363-883, Korea \\ ${ }^{\S}$ Department of Crops Biotechnology, College of Life Sciences and Natural Resources, Jinju National University, \\ Jinju, Gyeongnam 660-758, Korea \\ Received January 15, 2010, Accepted February 8, 2010
}

Key Words: Paederia scandens, Phenylpropanoids, Paederol A, Paederol B, Flavonoids

Paederia scandens (Lour.) Merrill (Rubiaceae) is a climbing plant, distributed in southern region of the Korea Peninsula, Vietnam, India, China, Japan, the Philippines, and the USA. ${ }^{1}$ The roots, leaves, bark, and fruits of this plant have been used to treat jaundice, dysentery, and dyspepsia, in Korea. ${ }^{2}$ Previous investigations on this plant have reported the occurrence of iridoid glycosides ${ }^{1,2,3}$ and the pharmacological activities including the inhibitory effects against Epstein-Barr virus activation $^{4}$ and xanthine oxidase, ${ }^{5}$ antinociceptive activity, ${ }^{6,7}$ and uricosuric effect. ${ }^{5}$ The present study described the isolation of two new phenylpropanoid glycosides $\mathbf{1}$ and $\mathbf{2}$, along with two known flavonoid glycosides $\mathbf{3}$ and $\mathbf{4}$ from the aerial parts of $P$. scandens. The structures of the known compounds 3 and $\mathbf{4}$ were confirmed by interpreting the measured 1D and 2DNMR spectroscopic data and comparing these data with the published values, rutin, and kaempferol-3-O-rutinoside, respectively. ${ }^{8}$ It is the first time that these isolates have been isolated from this plant.

Compound 1 was obtained as an amorphous powder, and its molecular formula of $\mathrm{C}_{22} \mathrm{H}_{32} \mathrm{O}_{13}$ was confirmed by the presence of a sodiated molecular ion $[\mathrm{M}+\mathrm{Na}]^{+}$at $m / z 527.1745$ in the HR FAB-MS. The ${ }^{1} \mathrm{H}-\mathrm{NMR}$ spectrum (Table 1) displayed a

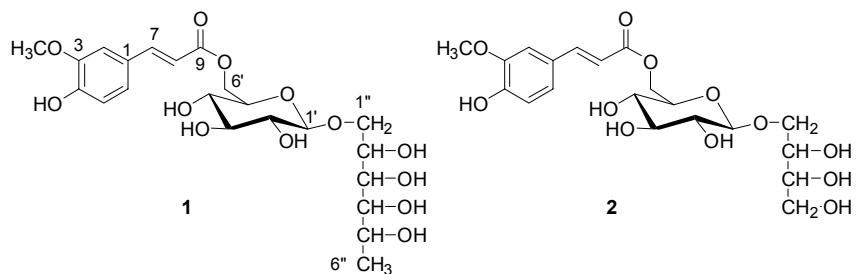

Figure 1. The chemical structures of $\mathbf{1}$ and $\mathbf{2}$.

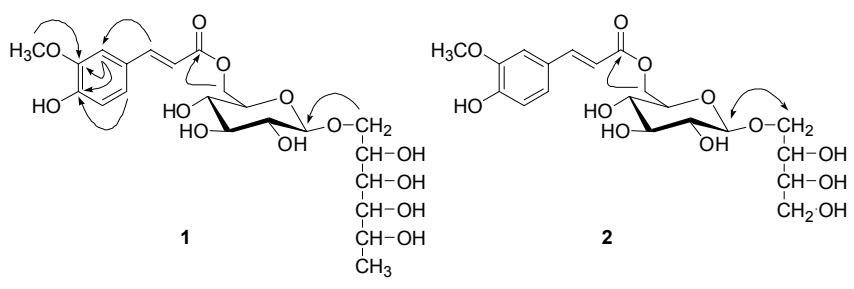

Figure 2. Key HMBC correlations of $\mathbf{1}$ and $\mathbf{2}$. singlet peak at $\delta_{\mathrm{H}} 7.19$, two doublet peaks at $\delta_{\mathrm{H}} 6.80(1 \mathrm{H}, J=$ $8.1 \mathrm{~Hz}, \mathrm{H}-5)$ and $7.06(1 \mathrm{H}, J=8.1 \mathrm{~Hz}, \mathrm{H}-6)$, two doublet peaks at $\delta_{\mathrm{H}} 7.63(1 \mathrm{H}, J=15.8 \mathrm{~Hz}, \mathrm{H}-7)$ and $6.39(1 \mathrm{H}, J=15.8 \mathrm{~Hz}, \mathrm{H}-8)$ due to trans oriented olefinic protons, and a methoxy peak at $\delta_{\mathrm{H}} 3.89$, which was assigned as a feruloyl group on the basis of further investigation using HMQC and HMBC spectra (Fig. 2). The proton signals at $\delta_{\mathrm{H}} 1.10-4.60$ seemed to comprise two sugar units. The assignments of these sugar signals were facilitated by the COSY and TOCSY techniques. An anomeric pro-

Table 1. ${ }^{1} \mathrm{H}$ and ${ }^{13} \mathrm{C}-\mathrm{NMR}$ chemical shifts of $\mathbf{1}$ and $\mathbf{2}$

\begin{tabular}{|c|c|c|c|c|}
\hline \multirow{2}{*}{ Position } & \multicolumn{2}{|l|}{1} & \multicolumn{2}{|l|}{2} \\
\hline & $\delta_{\mathrm{H}}$ & $\delta_{\mathrm{C}}$ (mult.) ${ }^{a}$ & $\delta_{\mathrm{H}}$ & $\overline{\delta_{\mathrm{C}}(\text { mult. })^{a}}$ \\
\hline 1 & - & $128.3(\mathrm{~s})$ & - & $128.5(\mathrm{~s})$ \\
\hline 2 & $7.19 \mathrm{~s}$ & $112.5(\mathrm{~d})$ & $7.20 \mathrm{~d} 1.6$ & $112.5(\mathrm{~d})$ \\
\hline 3 & - & $150.2(\mathrm{~s})$ & - & $150.2(\mathrm{~s})$ \\
\hline 4 & - & $151.6(\mathrm{~s})$ & - & $151.5(\mathrm{~s})$ \\
\hline 5 & $6.80 \mathrm{~d} 8.1$ & $117.3(\mathrm{~d})$ & $6.80 \mathrm{~d} 8.0$ & $117.3(\mathrm{~d})$ \\
\hline 6 & $7.06 \mathrm{~d} 8.1$ & $125.1(\mathrm{~d})$ & $7.07 \mathrm{dd} 8.0,1.6$ & $125.0(\mathrm{~d})$ \\
\hline 7 & $7.63 \mathrm{~d} 15.8$ & $148.0(d)$ & $7.63 \mathrm{~d} 15.9$ & $147.9(\mathrm{~d})$ \\
\hline 8 & $6.39 \mathrm{~d} 15.8$ & $116.0(\mathrm{~d})$ & $6.39 \mathrm{~d} 15.9$ & $116.0(\mathrm{~d})$ \\
\hline 9 & - & 169.9 (s) & - & 9 (s) \\
\hline $1^{\prime}$ & $4.35 \mathrm{~d} 7.6$ & $105.8(d)$ & $4.34 \mathrm{~d} 7.6$ & $105.8(\mathrm{~d})$ \\
\hline $2^{\prime}$ & $3.26 \mathrm{~m}$ & $76.0(\mathrm{~d})$ & $3.25 \mathrm{~m}$ & $76.0(d)$ \\
\hline $3^{\prime}$ & $3.38 \mathrm{~m}$ & $78.5(\mathrm{~d})$ & $3.38 \mathrm{~m}$ & $78.5(\mathrm{~d})$ \\
\hline $4^{\prime}$ & $3.38 \mathrm{~m}$ & $72.4(\mathrm{~d})$ & $3.38 \mathrm{~m}$ & $72.4(\mathrm{~d})$ \\
\hline $5^{\prime}$ & $3.54 \mathrm{~m}$ & $76.4(\mathrm{~d})$ & $3.56 \mathrm{~m}$ & 76.3 (d) \\
\hline $6^{\prime}$ & $\begin{array}{l}4.30 \mathrm{dd} 11.7,5.7 \\
4.51 \mathrm{dd} 11.7,2.1\end{array}$ & $65.4(\mathrm{t})$ & $\begin{array}{l}4.30 \mathrm{dd} 12.0,5.0 \\
4.51 \mathrm{dd} 12.0,1.8\end{array}$ & $65.4(\mathrm{t})$ \\
\hline $1^{\prime \prime}$ & $\begin{array}{l}4.11 \mathrm{dd} 10.2,2.2 \\
3.69 \mathrm{dd} 10.2,6.0\end{array}$ & $74.1(\mathrm{t})$ & $\begin{array}{l}4.08 \mathrm{dd} 9.1,2.1 \\
3.66 \mathrm{~m}\end{array}$ & $73.8(t)$ \\
\hline $2^{\prime \prime}$ & $3.82 \mathrm{~m}$ & $72.6(d)$ & $3.71 \mathrm{~m}^{b}$ & $73.3(\mathrm{~d})^{b}$ \\
\hline $3^{\prime \prime}$ & $3.58 \mathrm{~m}$ & $73.7(d)$ & $3.61 \mathrm{~m}^{b}$ & $74.3(\mathrm{~d})^{b}$ \\
\hline $4 "$ & $3.57 \mathrm{~m}$ & $75.6(d)$ & $\begin{array}{l}3.61 \mathrm{~m} \\
3.71 \mathrm{~m}\end{array}$ & $65.4(t)$ \\
\hline $5^{\prime \prime}$ & $3.84 \mathrm{~m}$ & $71.2(\mathrm{~d})$ & - & - \\
\hline $6^{\prime \prime}$ & $1.17 \mathrm{~d} 6.5$ & $20.4(q)$ & - & - \\
\hline $\mathrm{OCH}_{3}$ & $3.89 \mathrm{~s}$ & $57.3(\mathrm{q})$ & $3.87 \mathrm{~s}$ & $57.3(q)$ \\
\hline
\end{tabular}

${ }^{a}$ Multiplicity was deduced from the DEPT and HMQC spectroscopic data. ${ }^{b}$ Assignments are interchangeable. 
ton at $\delta_{\mathrm{H}} 4.35\left(1 \mathrm{H}, \mathrm{d}, J=7.6 \mathrm{~Hz}, \mathrm{H}-1^{\prime}\right)$ was coupled with a proton signal at $\delta_{\mathrm{H}} 3.26\left(1 \mathrm{H}, \mathrm{m}, \mathrm{H}-2^{\prime}\right)$ in the ${ }^{1} \mathrm{H}-{ }^{1} \mathrm{H}$ COSY and showed correlations with four proton signals $\left(\mathrm{H}-2^{\prime}, \mathrm{H}-3^{\prime}, \mathrm{H}-4^{\prime}\right.$, and $\left.\mathrm{H}-5^{\prime}\right)$ in the TOCSY spectrum. In addition, the couplings between $\mathrm{H}-5^{\prime}\left(\delta_{\mathrm{H}} 3.54\right)$ and $\mathrm{H}-6^{\prime}\left(\delta_{\mathrm{H}} 4.30\right.$ and 4.51$)$ were observed in the ${ }^{1} \mathrm{H}-{ }^{1} \mathrm{H}$ COSY and TOCSY. These data enabled the assignment of the signals belonging to a glucopyranoside together with DEPT and HMQC data. The remaining part was assigned as acyclic sugar moiety, a hexane-1,2,3,4,5-pentanol, by using the sequentially observed correlations from H-1" to H-6" in the ${ }^{1} \mathrm{H}-{ }^{1} \mathrm{H}$ COSY and the partially observed correlations of $\mathrm{H}-1$ " to H-2", H-3", and H-4" in the TOCSY spectra, as well as examination of DEPT, HMQC, and HMBC data. ${ }^{9,10}$ The connection between feruloyl and glucose was confirmed by the HMBC correlations (Fig. 2$)$ from $\mathrm{H}-6^{\prime}\left(\delta_{\mathrm{H}} 4.30,4.51\right)$ to $\mathrm{C}-9\left(\delta_{\mathrm{C}} 169.9\right)$. The chemical shift of C-1" $\left(\delta_{\mathrm{C}} 74.1\right)$ and three-bond correlations between $\mathrm{H}-1^{\prime \prime}\left(\delta_{\mathrm{H}} 4.11\right.$ and 3.69$)$ and $\mathrm{C}-1^{\prime}\left(\delta_{\mathrm{C}} 105.8\right)$ made it possible to locate the hexane-1,2,3,4,5-pentanol on $\mathrm{C}-1$ '. However, the absolute configurations of the sugars in 1 were not determined. Therefore, the structure of this compound (1) was established as hexane-1,2,3,4,5-pentanol 1-O- $\beta-(6-O-(E)-$ feruloyl) glucopyranoside, and it has been named paederol $\mathrm{A}$.

The molecular formula of compound $2, \mathrm{C}_{20} \mathrm{H}_{28} \mathrm{O}_{12}$, was deduced from the quasimolecular ion peak at $\mathrm{m} / z$ 483.1464 [M+Na] $]^{+}$ in the HRFABMS. The comparison of ${ }^{1} \mathrm{H}$ and ${ }^{13} \mathrm{C}$ NMR spectral data of $\mathbf{2}$ with those of $\mathbf{1}$ revealed the presence of an identical feruloyl glucose unit in $\mathbf{1}$ as well as a different sugar moiety from 1. Two oxymethylene signals of $\mathrm{H}-1$ " $\left(\delta_{\mathrm{H}} 4.08\right.$ and 3.66), and $\mathrm{H}-4$ " $\left(\delta_{\mathrm{H}} 3.61\right.$ and 3.71), and two oxymethine signals of $\mathrm{H}-3{ }^{\prime \prime}$ $\left(\delta_{\mathrm{H}} 3.61\right)$ and $\mathrm{H}-2^{\prime \prime}\left(\delta_{\mathrm{H}} 3.71\right)$ were observed in the ${ }^{1} \mathrm{H}$, DEPT, and HMQC data, indicating a butane 1,2,3,4-tetraol moiety. This assumption was supported by comparing ${ }^{1} \mathrm{H}$ and ${ }^{13} \mathrm{C}$ chemical shifts of $\mathbf{2}$ with published values. The downfield-shifted chemical shift of $\mathrm{C}-1^{\prime \prime}\left(\delta_{\mathrm{C}} 73.8\right)$ and the HMBC correlations between $\mathrm{H}-1$ " and $\mathrm{C}-1^{\prime}\left(\delta_{\mathrm{C}} 105.8\right)$ as well as $\mathrm{H}-1^{\prime}$ and $\mathrm{C}-1^{\prime \prime}$ confirmed the location of butane tetraol on $\mathrm{C}-1^{\prime}$ through ether linkage. Accordingly, this compound (paederol B) was determined to be a butane-1,2,3,4-tetraol 1-O- $\beta-(6-O-(E)$-feruloyl) glucopyranoside. The absolute configurations of the sugars remained unresolved in the present study. To our knowledge, thus far, there has been no report of phenylpropanoid glycosides with acyclic sugars.

Among the isolates, the two new compounds $\mathbf{1}$ and $\mathbf{2}$ were tested for cytotoxicity against three human cancer cell lines, Lu1 (lung cancer), LNCaP (prostate cancer), and MCF-7 (breast cancer) but were found to be inactive $\left(\mathrm{ED}_{50}>10 \mu \mathrm{g} / \mathrm{mL}\right)$.

\section{Experimental Section}

General procedures. Optical rotation was measured with a JASCO DIP-1000 digital polarimeter (Tokyo, Japan). FAB-MS spectra were obtained on a JEOL JMS-AX505WA. UV and IR spectra were recorded on a Shimadzu UV-2101 and JASCO FT/IR-300E, respectively. ${ }^{1} \mathrm{H}-\mathrm{NMR}$ and ${ }^{13} \mathrm{C}-\mathrm{NMR}$ spectra were recorded on a Bruker spectrometer at $400 \mathrm{MHz}$ and at $100 \mathrm{MHz}$, respectively. Column chromatography was performed using a Sephadex LH-20 (Pharmacia) and Kiesegel 60 (Art. 7734; Merck, Darmstadt, Germany). HPLC was performed on a co- lumn of YMC (J'sphere ODS-H80, S-4 $\mu \mathrm{m}, 250 \times 10 \mathrm{~mm}$ i.d., Japan). TLC was conducted on pre-coated Kiesegel $60 \mathrm{~F}_{254}$ plates (Art. 5715; Merck, Darmstadt, Germany). Spots on the TLC were detected under UV light.

Plant materials. The aerial parts of $P$. scandens were collected from Chusan Experimental Station of Southern University Forest, College of Agricultural \& Life Sciences, Seoul National University in 2002. A voucher specimen (SNUPC-012) was deposited at the College of Pharmacy at Seoul National University.

Extraction and isolation. The aerial parts of $P$. scandens $(3.0$ $\mathrm{kg}$ ) were dried at room temperature and then extracted with $\mathrm{MeOH}$. The $\mathrm{MeOH}$ extract (340 g) was concentrated in vacuo into a residue, which was suspended with water and then subsequently partitioned with $n$-hexane ( $2 \mathrm{~L}), \mathrm{CH}_{2} \mathrm{Cl}_{2}(2 \mathrm{~L})$, EtOAc ( $2 \mathrm{~L})$, and $n-\mathrm{BuOH}(2 \mathrm{~L})$, successively. The $n$-BuOH soluble fraction $(46.0 \mathrm{~g}$ ) was fractionated using silica gel column chromatography $\left(\mathrm{CHCl}_{3}-\mathrm{MeOH}=10: 1 \rightarrow 1: 1\right)$ into twelve fractions (PB 1 12). The PB 8 fraction (3.3 g) was subjected to reversedphase $\mathrm{C}_{18}$ column chromatography $\left(\mathrm{MeOH}-\mathrm{H}_{2} \mathrm{O}=2: 8 \rightarrow 5: 5\right)$ and produced four sub-fractions (PB 81 84). The PB 83 was applied to Sephadex LH-20 (MeOH) and then separated using HPLC $\left(\mathrm{MeCN}-\mathrm{H}_{2} \mathrm{O}=17: 83,2 \mathrm{~mL} / \mathrm{min}\right)$ to yield compound 2 $\left(5.0 \mathrm{mg}, t_{\mathrm{R}} 32.9 \mathrm{~min}\right)$. The PB 9 (2.7 g) was subjected to reversed-phase $\mathrm{C}_{18}$ column chromatography $\left(\mathrm{MeOH}-\mathrm{H}_{2} \mathrm{O}=2: 8 \rightarrow\right.$ 5:5) and produced five sub-fractions (PB 91 PB 95). The combined PB 92 and PB 93 was fractionated by Sephadex LH-20 into four fractions (PB 931 934). From the PB 934, compound 1 (3.4 mg, $t_{\mathrm{R}} 36.47 \mathrm{~min}$ ) was purified using HPLC $\left(\mathrm{MeCN}-\mathrm{H}_{2} \mathrm{O}=17: 83,2 \mathrm{~mL} / \mathrm{min}\right)$. The $\mathrm{PB} 94$ was subjected to Sephadex LH-20 (MeOH) and yielded four sub-fractions (PB 941 944). The PB 943 was applied to HPLC $\left(\mathrm{MeCN}-\mathrm{H}_{2} \mathrm{O}=\right.$ 10:90, $2 \mathrm{~mL} / \mathrm{min}$ ) and afforded compounds 3 (34 mg, $t_{\mathrm{R}} 13.41$ $\mathrm{min})$ and 4 (10.0 $\left.\mathrm{mg}, t_{\mathrm{R}} 17.86 \mathrm{~min}\right)$.

Compound 1 (paederol A): amorphous solid; HR FAB-MS $m / z 527.1745[\mathrm{M}+\mathrm{Na}]^{+}$(Calcd for $\mathrm{C}_{22} \mathrm{H}_{32} \mathrm{O}_{13} \mathrm{Na}, 527.1741$ ); $[\alpha]_{\mathrm{D}}^{20}-11.0^{\circ}(c 0.16, \mathrm{MeOH}) ; \mathrm{UV} \lambda_{\max }(\mathrm{MeOH}) \mathrm{nm}(\log \varepsilon): 233$ (3.94), 324 (4.10); IR $v_{\max }\left(\mathrm{KBr}, \mathrm{cm}^{-1}\right)$ 3367, 2929, 1696, $1631,1596,1515,1275,1169,1077 ;{ }^{1} \mathrm{H}-\mathrm{NMR}\left(\mathrm{CD}_{3} \mathrm{OD}\right)$ and ${ }^{13} \mathrm{C}$-NMR $\left(\mathrm{CD}_{3} \mathrm{OD}\right)$ see Table 1.

Compound 2 (paederol B): amorphous solid; HR FAB-MS $m / z$ 483.1464 [M+Na] ${ }^{+}$(Calcd for $\mathrm{C}_{20} \mathrm{H}_{28} \mathrm{O}_{12} \mathrm{Na}, 483.1478$ ); $[\alpha]_{\mathrm{D}}^{20}-16.2^{\circ}$ ( c 0.14, MeOH); UV $\lambda_{\max }(\mathrm{MeOH}) \mathrm{nm}(\log \varepsilon): 233$ (3.97), 323 (4.14); IR $v_{\max }\left(\mathrm{KBr}, \mathrm{cm}^{-1}\right)$ 3393, 2932, 1696, $1631,1596,1515,1274,1172,1078 ;{ }^{1} \mathrm{H}-\mathrm{NMR}\left(\mathrm{CD}_{3} \mathrm{OD}\right)$ and ${ }^{13} \mathrm{C}$-NMR $\left(\mathrm{CD}_{3} \mathrm{OD}\right)$ see Table 1.

Cytotoxicity evaluation. All the isolates were assessed with the Lu1 (human lung carcinoma), LNCaP (hormone-dependent human prostate carcinoma), and MCF-7 cancer cell lines, using established protocols. ${ }^{11}$

Acknowledgments. We are grateful to Jong-Young Park, Chusan Experimental Station of Southern University Forest.

\section{References}

1. Quang, D. N.; Hashimoto, T.; Tanaka, M.; Dung, N. X.; Asakawa, Y. Phytochemistry 2002, 60, 505.

2. Kim, Y. L.; Chin, Y.-W.; Park, J. H.; Kim, J. Chem. Pharm. Bull. 2004, 53, 103 . 
3. Otsuka, H. Natural Medicines 2002, 56, 59 .

4. Kapadia, G. J.; Sharma, S. C.; Tokuda, H.; Nishino, H.; Ueda, S. Cancer Lett. 1996, 102, 223.

5. Yan, H.; Ma, Y.; Liu, M.; Zhou, L. Planta Med. 2008, 74, 1345.

6. Chen, Y.-F.; Li, N.; Jiao, Y.-L.; Wei, P.; Zhang, Q.-Y.; Rahman, K.; Zheng, H.-C.; Qin, Lu-P. Phytomedicine 2008, 15, 427.

7. Chen, Y.-F.; Huang, Y.; Tang, W.-Z.; Qin, L.-P.; Zheng, H.-C. Pharmacol. Biochem. Behav. 2009, 93, 97.
8. Kim, S. Y.; Gao, J. J.; Lee, W.-C.; Ryu, K. S.; Lee, K. R.; Kim, Y. C. Arch. Pharm. Res. 1999, 22, 81.

9. Kitajima, J.; Ishikawa, T.; Tanaka, Y.; Ida, Y. Chem. Pharm. Bull. 1999, 47, 988 .

10. Matsumura, T.; Ishikawa, T.; Kitajima, J. Phytochemistry 2002, $61,455$.

11. Likhitwitayawuid, K.; Angerhofer, C. K.; Cordell, G. A.; Pezzuto, J. M.; Ruangrungsi, N. J. Nat. Prod. 1993, 56, 30. 